\title{
OVERWEIGHT AND OBESITY RISK ASSESSMENT - TWO METHODS, DIFFERENT RESULTS
}

Cristiana Lucretia Pop

Physical Education and Sport Department, Bucharest Economic Studies University

\begin{abstract}
Purpose: the purpose of this study was to verify if there is any significant difference between body fat assessment by calculating body mass index and by using bioelectrical impedance analysis. Materials: subsequently we determined the ratio between body fat and muscular mass percentage in a sample of 156 university girl students. Results: BMI and muscle mass percentage seem to have similar variance and trends, while body fat exceeded in numbers and percents the highest levels of BMI. While by calculating BMI the found number of overweight and obese subjects was 23 from the total of 156 , (14\%); by measuring body fat percentage that number increased to $67(43 \%)$ of girl students in the sample. The $t$ test showed significant difference between BMI values and the body fat percentage for the study sample: $\mathrm{t}(155)=2.37, \mathrm{p}<0.01$. Conclusions: this study supports the idea that BMI results may be insufficient for correct assessment of overweight and obesity risk. Body composition adds useful information about health and fitness. A few concluding recommendations, regarding beneficial effects of exercise, have been made aiming to provide students of all body parameters with meaningful, relevant and positive physical education and health knowledge.
\end{abstract}

Key words: Body composition, girl students, body fat, fitness, health.

\section{Introduction}

A report of Organization for Economic Cooperation and Development (OECD) entitled 'Health at a Glance: Europe 2012' says that more than half (52\%) of the total adult population across the European Union are now overweight or obese [22]. Explanation implies balance between sedentary behavior and physical activity and the changes in people's nutrition habits after the half of the 20th century. In this postindustrial society, technology development replaced human work force with machines reducing gradually people's physical labor. Nurturing habits and customs did change, and they were influenced in many different ways by urbanization, technology progress and globalization. This three factors have often resulted in diets, in which an important percentage of energy intake comes from industrial processed food, associated with an increased consumption of sugar, fats, and salt [14].

Poor eating is leading to a range of physical health problems and some psychological after effects as well. Overweight problems of children and young people are associated with asthma, type 2 diabetes, depression, being bullied, learning difficulties, low self confidence and social reluctance; the greater body mass index is, the greater are risks to health and precarious quality of life.

In spite of wide interest to body weight assessment and physical appearance, most individuals are not aware of how much fat they deposit in their bodies. The most used equation for approximate the body fat is body mass index (BMI). A report by World Health Organization (1995) warned that row BMI data might create confusion between muscularity and overweight. De Lorenzo et al. (2001) suggested that BMI reliability for measuring body fat is questionable, and recommended direct measurement of body fat for an accurate diagnosis of overweight and obesity.

The purpose of this study is to verify if there is any significant difference between body fat estimation by calculating body mass index and by using bioelectrical impedance analysis. Subsequently we studied the ratio between body fat and muscular mass percentage in a sample of young Romanian women.

\section{Material and methods}

The objective issues of weight management tackled in this paper are weight, body mass index and body composition. The study sample consisted of 156 girl students, between 19 and 24 years' age, randomly selected from those who attended weekly physical education sessions. For objective data collection we used anthropometrical measurements - height and weight - which enable us to calculate Body Mass Index (BMI) and body composition.

BMI is a measure of body fat based on height and weight; its normal range is usually considered as 18.5 to $24.99 \mathrm{~kg} / \mathrm{cm}^{2}$; with it, values 25 are considered as overweight and over 30 - as obese. Body composition was assessed with a bioelectrical impedance analysis technology. It showed data about body fat and muscle mass percentage.

Body fat (BF) percentage, referred to as relative body fat, was obtained by dividing fat mass by total body weight. Average BF percentage was 15 for men and 23 for women. Obesity, which may be defined as an excessive

(C) Pop Cristiana Lucretia, 2015

doi:10.15561/20755279.2016.0307 
amount of total body fat for a given body weight, was identified as excessive body fat $25 \%$ for men and $32 \%$ for women. Wilmore, Buskirk, DiGirolamo \& Lohman (1986) indicated some referential values for body fat assessing:

\begin{tabular}{ll}
\hline Essential fat & $<8$ \\
\hline Minimal fat & $15 \%$ \\
Most athletes & $12-22 \%$ \\
Optimal health & $18-30 \%$ \\
Optimal fitness & $16-25 \%$ \\
Overweight \& Obesity & $>30 \%$ \\
\hline
\end{tabular}

Adapting the standards to our sample characteristics we compared body fat percentage data in our study with the Standards of Fatness for Women in Percent Body Fat [10]. It considered the average as 23\% and also a normal interval between 9 and 22\% (below average) and between 24 and 31.9\% (above average). Body fat values below $8 \%$ represent a risk of diseases and disorders associated with wrong eating and above $31 \%$ are a marker of diseases associated with obesity.

Beside descriptive statistic analysis, the paired-samples " $t$ ” test was calculated for comparison between data sets.

\section{Results}

Average weight of adult person is $62 \mathrm{~kg}$ according to a league table of the world's 'fattest' nations from London School of Hygiene \& Tropical Medicine [18]. In this table Romania has a middle range: 95 from 177 countries with an average weight of $66.4 \mathrm{~kg}$. Girl students in our sample had average weight of $58 \mathrm{~kg}$, with 1.65 $\mathrm{m}$ average height, resulting in average BMI value of $21.2 \mathrm{~kg} / \mathrm{m}^{2}$, corresponding to a slander feminine silhouette. In the next table we present descriptive statistic data for three studied variable:

Table 1. Descriptive statistic

\begin{tabular}{llll}
\hline Variable & BMI & Body fat & Muscle mass \\
\hline Mean & 21.2 & $28.75 \%$ & $29 \%$ \\
Median & 20.45 & 28.6 & 28.85 \\
Mode & 18.5 & 28.6 & 29 \\
SD & 3.54 & 8.2 & 3.85 \\
Sample variance & 12.57 & 67.27 & 14.82 \\
Minimum & 15.1 & 8.9 & 15.6 \\
Maximum & 36.6 & 51.1 & 44.7 \\
Count & 156 & 156 & 156 \\
\hline
\end{tabular}

Taking into account BMI values and its corresponding classification we obtain the following results:

Table 2. BMI results

\begin{tabular}{lllll}
\hline $\begin{array}{l}\text { Underweight } \\
>\mathbf{1 8 . 5} \mathbf{~ k g} / \mathbf{m}^{\mathbf{2}}\end{array}$ & $\begin{array}{l}\text { Normal weight } \\
\mathbf{1 8 . 5} \mathbf{2 4 . 9}\end{array}$ & $\begin{array}{l}\text { Overweight } \\
\mathbf{2 5 - 2 9 . 9}\end{array}$ & $\begin{array}{l}\text { Obese } \\
<\mathbf{3 0} \mathbf{~ k g} / \mathbf{m}^{\mathbf{2}}\end{array}$ \\
\hline units & 37 & 97 & 19 & 4 \\
$\%$ & $23.6 \%$ & $61.78 \%$ & $11.46 \%$ & $2.55 \%$ \\
\hline
\end{tabular}

According to BMI values almost $62 \%$ of the subjects are in the normal weight group, $14 \%$ are overweight and obese and the rest $23.6 \%$ are underweight.

Body fat percentage measurement showed different results:

Table 3. Body fat results

\begin{tabular}{lllll}
\hline $\begin{array}{l}\text { Minimal fat } \\
>\mathbf{1 5} \%\end{array}$ & $\begin{array}{l}\text { Optimal fit } \\
\mathbf{1 5} \mathbf{2 4 . 9 \%}\end{array}$ & $\begin{array}{c}\text { Optimal health } \\
\mathbf{2 5} \mathbf{2 9 . 9 \%}\end{array}$ & $\begin{array}{l}\text { Overweight \& } \\
\text { Obese }<\mathbf{3 0} \%\end{array}$ \\
\hline units & 5 & 45 & 39 & 67 \\
$\%$ & $3 \%$ & $29 \%$ & $25 \%$ & $43 \%$ \\
\hline
\end{tabular}


From this point of view the number of subjects presenting an important percentage of body fat surpasses by far optimistic result of BMI calculated previously.

Table 4. Muscular mass results

\begin{tabular}{lllll}
\hline$<35 \%$ & & $34.9-30 \%$ & $\mathbf{2 5 - 2 9 . 9 \%}$ & $<\mathbf{2 5 \%}$ \\
\hline units & 8 & 41 & 95 & 12 \\
$\%$ & $5 \%$ & $26.4 \%$ & $61 \%$ & $7.7 \%$ \\
\hline
\end{tabular}

The muscular mass percentage mean value in our sample was $29 \%$, i.e. higher than the reference mean value of $23 \%$. We consider it normal, given the homogenous sample of very young women and being known that lean body mass is decreasing with age.

\section{Discussion}

The ratio body fat percentage of muscle/mass, measured in the research sample, revealed that in 81 of subjects muscle mass percentage is bigger than body fat percentage; in 2 cases those two variables were equal and in 73 subjects body fat percentage was higher than muscle mass. Fat tissue contains no water and has bigger volume comparative with muscle tissue, which has higher density. The higher is the percentage of body fat, the higher the overall body volume is. Body fat percentage also directly correlates with increased health risk, especially in respect to metabolic and cardiovascular diseases $[3,5,16]$.

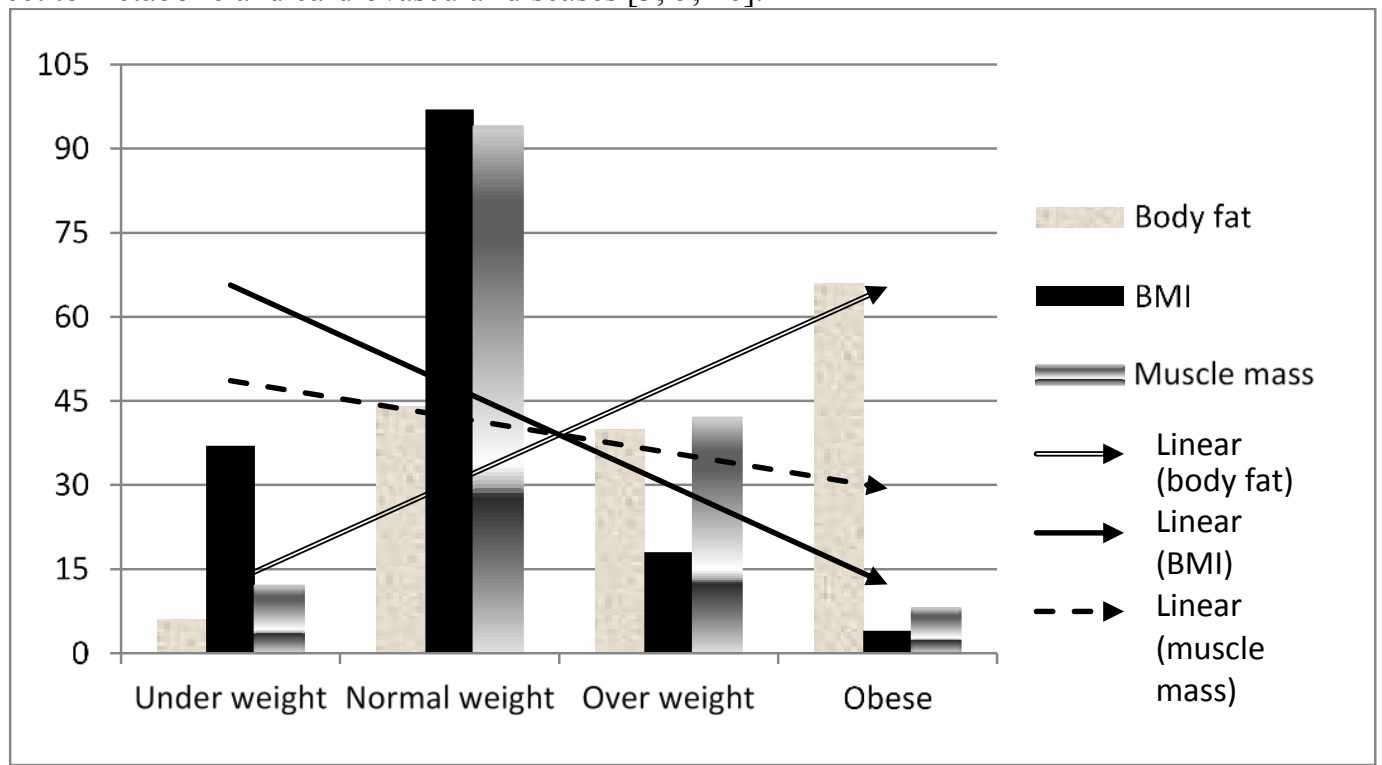

Fig. 1 Data distribution and trend lines for 3 variables

As the figure above shows, there is significant difference between the variance of three variables presented in this research: BMI and muscle mass percentage seem to have similar variance and trends, while body fat exceeded in numbers and percents the levels of BMI of the obese.

Calculating BMI, the determined number of overweight and obese subjects was 23 from the total of 156, (14\%), while by measuring body fat percentage that number increased three times $(43 \%)$ of girls students in our sample. In other words $20 \%$ of girl students were in normal weight group, because of high body fat percentage, could be considered actually overweight. "T" test showed significant difference between BMI values and body fat percentage in the studied sample: $\mathrm{t}(155)=2.37, \mathrm{p}<0.01$. While BMI may give an individual a general idea of increased risk of obesity-related health problems, it fails to distinguish the composition of that weight [8].

In most countries the rise in obesity has affected all population groups, regardless gender, age, race; income or education level. Evidences from a number of countries, including Austria, England, France, Italy and Spain, indicate that obesity tends to be more common among individuals in disadvantaged socio-economic groups, being particularly strong among women [15]. There is also a relationship between the number of years, spent in full-time education and obesity, with the most educated individuals displaying lower rates; with it the gradient of obesity is stronger in women than in men [21]. "Educational achievements correlate with higher earnings through access to 
better job opportunities and social networks, which in the long term are expected to translate into higher health expenditures and thus better health" [7].

Physical activity has an indubitable beneficial effect on some aspects of quality of life. In the past years of 21 -st century mounting research has shown how lifestyle changes, including exercise, stress management, and diet can prevent almost ninety percent of chronic illnesses in our society [4].

Regarding the effect of exercise, localized in a specific body part Anikieiev (2015), analyzing a number of studies, concluded that contribution of fat oxidation to muscles functioning energy supply is extremely little [2]. Actually only main metabolism can be supplied by fat oxidation [17] and consecutively the skin fold thickness will not decrease in that specific spot because the surrounding muscles work out. Fat loss comes down not due to targeted exercises, but owing to the basic principle of how many calories you expend versus how many you take in [12]. Combining cardiovascular exercise with weight training and correct eating seems to be right approach to more fat than weight loss [19].

\section{Conclusion}

BMI results may be insufficient for a correct estimation of overweight and obesity risk. The body composition adds useful information about health and fitness status.

Physical education and sport instructors should have supporting and encouraging attitude and motivate students for physical effort. Satisfaction, gained from exercising, can eventually become a motivation in itself, especially when the effort has positive effects on enhancing perceptions of health and overall well-being.

A few concluding recommendations can lead to an enhancement of vigor and health for students of all ages and body parameters:

- $\quad$ To encourage young people to set realistic and feasible goals and motivate them to keep weight under control by combining eating and physical activities;

- To establish a good relationship between effort and recovery and, at the same time, to make clear that individuals are responsible for their own success or failure;

- Exercise enjoyment is positively associated with motivation for physical effort. Physical education instructors can enhance enjoyment by creating good working climate, by adding variety to workouts, and by ensuring that the fitness programs are physically challenging and meet the subject's preferences and personal goals;

- To provide all young people, of allbody parameters, with meaningful, relevant and positive physical education and health knowledge and eventually to deliver healthy, valuable graduates for society.

Integrating physical and health education in preventative strategies would have better effect in reducing overweight and obesity among university students and co-morbidities associated with these later, during life [14].

\section{Conflict of interests}

The author has no conflict of interests to declare.

\section{References}

1. Anikieiev DM. Change of body composition in process of power conditional training. Pedagogic, psychology, medical-biological problems of physical training and sports, 2015;12:11-15. doi:10.15561/18189172.2015.1202

2. Clark MA, Lucett SC, Corm RJ. NASM Essentials of Personal Fitness Training: course manual. Philadelphia; Baltimore: Wolters Kiuwer: Lippincott Williams \& Wilkins; 2008.

3. Cho YG, Song HJ, Kim JM, Park KH, Paek YJ, Cho JJ, Caterson I, Kang JG. The estimation of cardiovascular risk factors by body mass index and body fat percentage in Korean male adults. Metabolism. 2009;58(6):765771. doi:10.1016/j.metabol.2009.01.004

4. Chopra D. State of Health: Prevention is What Matters. Health, 2014;7:11-14. Available at: https://www.deepakchopra.com/blog/article/4770 (accessed February 2015).

5. Chuang HH, Li WC, Sheu BF, Liao SC, Chen JY, Chang KC, Tsai YW. Correlation between body composition and risk factors of cardiovascular disease and metabolic syndrome. Biofactors. 2012;38:284291. doi:10.1002/biof.1027

6. De Lorenzo A, Deurenberg P, Pietrantuono M, Di Daniele N, Cervelli V, Andreoli A. How fat is obese? ActaDiabetol, 2003;40:254-257.

7. Devaux M, Sassi F. Social inequalities in obesity and overweight in 11 OECD countries. European Journal of Public Health, 2013;28(3):464-469.

8. Esmat T. Measuring and Evaluating Body Composition. ACSM Fit Society Page, 2010;1:3-10.

9. Haas BK. Clarification and integration of similar quality of life concepts. Image J Nurs Sch. 1999;31(3):215220. 
10. Heyward VH, Stolarczyk LM. Applied body composition assessment. Champaign: Human Kinetics; 1996.

11. Marković-Jovanović SR, Stolić RV, Jovanović AN. The reliability of body mass index in the diagnosis of obesity and metabolic risk in children. Journal of Pediatric Endocrinology and Metabolism. 2014;28(56):515-523. doi:10.1515/jpem-2014-0389

12. Perry E. Targeted Fat Loss: Myth or Reality? Yale Scientific Magazine. 2011;3:23-30. Available at: http://www.yalescientific.org/2011/04/targeted-fat-loss-myth-or-reality (accessed 23.04.2016)

13. Pop CL. Physical and health education facing the technology challenge. Physical Education of Students, 2016;2:45-49. doi:10.15561/20755279.2016.0207

14. Pop CL. Physical and Health Education for a Resilient Future Workforce. Revista Romaneasca pentru Educatie Multidimensionala, (2015). 7(2), 133-140. doi:10.18662/rrem/2015.0702.12

15. Suhrcke M, de Paz Nieves C. The impact of health and health behaviours on educational outcomes in high income countries: a review of the evidence. Copenhagen: WHO Regional Office for Europe; 2011.

16. Tanaka S, Togashi K, Rankinen T, Pérusse L, Leon AS, Rao DC, Skinner JS, Wilmore JH, Bouchard C. Is adiposity at normal body weight relevant for cardiovascular disease risk? Int J Obes Relat Metab Disord. 2002;26(2):176-183. doi:10.1038/sj.ijo.0801880.

17. Volkov NI, Osipenko AA, Nesen EN, Korsun SN. Biokhimiia myshechnoj deiatel'nosti [Bio-chemistry of muscular functioning], Kiev: Olympic Literature; 2000.

18. Walpole SC, Prieto-Merino D, Edwards P, Cleland J, Stevens G, Roberts I. The weight of nations: an estimation of adult human biomass, BMC Public Health 2012,12:439-443.

19. Willis LH, Slentz CA, Bateman LA, Shields AT, Piner LW, Bales CW, Houmard JA, Kraus WE. Effects of aerobic and/or resistance training on body mass and fat mass in overweight or obese adults. J Appl Physiol. 2012;113(12):1831-1837.

20. Wilmore JH, Buskirk ER, DiGirolamo M, Lohman TG. Body composition - around table. The Physician and Sports Medicine, 1986:14,144-162.

21. OECD/European Union Health at a Glance: Europe 2010. OECD Publishing; 2010:72-73.

22. OECD/European Union Health at a Glance: Europe 2010. OECD Publishing; 2012: 62-65. doi:10.1787/9789264183896-en.

\section{Information about the author:}

Cristiana Lucretia Pop; Professor PhD; http://orcid.org/00000002-6445-8702; crispotir@yahoo.com; Physical Education and Sport Department, Bucharest Economic Studies University; Piata Romana no. 6, sector 1, Bucuresti, 010374, Romania.

Cite this article as: Pop Cristiana Lucretia. Overweight and obesity risk assessment - two methods, different results. Physical education of students, 2016;3:53-57. doi:10.15561/20755279.2016.0307

The electronic version of this article is the complete one and can be found online at: http://www.sportpedu.org.ua/html/arhive-e.html

This is an Open Access article distributed under the terms of the Creative Commons Attribution License, which permits unrestricted use, distribution, and reproduction in any medium, provided the original work is properly cited (http://creativecommons.org/licenses/by/4.0/deed.en).

Received: 13.05 .2016

Accepted: 23.05.2016; Published: 28.06.2016 